regard themselves as ill pointed their joints as the reason for it, although $30 \%$ of them had extra articular manifestations.

Conclusion Most of the people suffering from BJHS consider themselves ill. BJHS should be looked at as a disease by the Physician.

\section{THU0234 FAMILIAL MEDITERRANEAN FEVER: ANALYSIS OF 45 TUNISIAN PATIENTS}

SS Turki, CH Ben Taarit, R Goucha, E Abderrahim, F Ben Moussa, H Ben Maiz. Department of Nephrology and Internal Medicine, Charles Nicolle Hospital, Tunis, Tunisia

\subsection{6/annrheumdis-2001.766}

Background Familial mediterranean fever (FMF) is an inherited multisystem disease of unknown aetiology, characterised by recurrent, painful, self-limited episodises.

Objectives The objectives of this study is to describe the clinical profile, course and complications of 45 cases of FMF observed over a period of 25 years.

Methods Retrospective review of 45 cases with FMF.

Results Forty patients (88\%) started their illness below the age of 10 years. Peritonitis occured in $84,4 \%$, arthritis in $35,5 \%$, pleuretis in $17,7 \%$ and erysipelas-like lesions in $31,1 \% .21$ patients developed renal amyloïdosis and 17 patients were subjected to unnecessary operative surgery.

The arthritis was monoarticular in $85 \%$ and polyarticular in $15 \%$ and was seronegative in all cases (Rheumatoid factor and antinuclear antibodies). The synovial attack showed a wide variation in the clinical presentation, course and duration of arthritis causing diagnostic difficulties.

Renal amyloïdosis occured in 21 patients after a mean duration of FMF 10,5 years ( 2 to 28 years). One patient had hematuria, kidney biopsy showed mesangial IgA glomerulonephritis. Among 32 patients treated with colchicine, $80 \%$ achieved a therapeutic response.

Conclusion FMF is an inherited disease; colchicine remains the only efficient treatment to prevent both acute manifestations and amyloïdosis.

\section{THU0235 TREATMENT OF REFRACTORY POSTERIOR UVEITIS WITH ANTI-TNF-ALFA (INFLIXIMAB)}

A Banares, E Pato, L Abasolo, P Macarron, C Hernandez, JA Jover, B Fernandez. Rheumatology, Hospital Clinico San Carlos, Madrid, Spain

\subsection{6/annrheumdis-2001.767}

Background There is a group of patients with non-infectious posterior uveitis (PU) who are refractory to corticosteroid or immunosuppressive (IS) regimens. The important role played by TNF-a in experimental uveitis models, and the efficacy shown by the various anti-TNF-a agents in autoimmune diseases have been reported.

Objectives To demonstrate the usefulness of infliximab in the treatment of non-infectious PU.

Methods Open, non-controlled trial, including 7 patients with corticosteroid-refractory PU who were receiving one or more of the following IS agents for a minimum of 2 years: CsA, AZA, MTX. Treatment was administered on a compassionate use basis, after EC approval at our institution and patient informed consent. All IS agents except MTX were discontinued one month prior to the start of treatment. Prednisone dose was adjusted to
$0.5 \mathrm{mg} / \mathrm{kg} / \mathrm{day}$ and decreased by $5 \mathrm{mg} / \mathrm{day}$ every week in the absence of posterior pole inflammation. Three doses of $5 \mathrm{mg} / \mathrm{kg}$ infliximab were administered IV at weeks 0,2 , and 6 . Visits including a full ophthalmological assessment took place at weeks $1,3,4,5,7,8$, and 12; fluorescein angiographies (FAG) and retinograms were performed at baseline and week 16 .

Results No adverse effects, and no ocular or systemic exacerbations were observed. Final prednisone dose was $=$ or $<7.5 \mathrm{mg}$ for six patients, and $15 \mathrm{mg}$ for patient 2. Vitreous haze improved in all patients except patient 7. Measurable improvement of visual acuity was documented in patients $2,3,4,5$, and 6. FAGs and retinograms confirmed vitreous clearance in all patients, showing improvement of active retinal bleeding in patient 4 and disappearance of a macular oedema (which had been present for years) in patient 5 . Only patient 7 , with chronic multifocal choroiditis, had no improvement.

\begin{tabular}{|c|c|c|c|c|c|c|}
\hline & Diagnosis & $\begin{array}{l}\text { Posterior } \\
\text { pole }\end{array}$ & $\begin{array}{l}\text { Visual } \\
\text { acuity* } \\
\text { Snellen } \\
\text { scale } \\
\text { Baseline }\end{array}$ & $\begin{array}{l}\text { Visual } \\
\text { acuity* } \\
\text { Snellen } \\
\text { scale } \\
\text { Week12 }\end{array}$ & $\begin{array}{l}\text { Vitreous } \\
\text { haze } \\
\text { Nussenblatt } \\
\text { scale } \\
\text { Baseline }\end{array}$ & $\begin{array}{l}\text { Vitreous } \\
\text { haze } \\
\text { Nussenblatt } \\
\text { scale } \\
\text { Week12 }\end{array}$ \\
\hline $\begin{array}{l}\text { Patient } \\
1\end{array}$ & $\begin{array}{l}\text { Behcet } \\
\text { dis. }\end{array}$ & Vasculitis & $20 / 25$ & $20 / 25$ & 0 & 0 \\
\hline $\begin{array}{l}\text { Patient } \\
2\end{array}$ & $\begin{array}{l}\text { Behcet } \\
\text { dis. }\end{array}$ & Vasculitis & $20 / 32$ & $20 / 28$ & \pm & 0 \\
\hline $\begin{array}{l}\text { Patient } \\
3\end{array}$ & $\begin{array}{l}\text { Behcet } \\
\text { dis. }\end{array}$ & Vasculitis & $20 / 32$ & $20 / 28$ & \pm & 0 \\
\hline $\begin{array}{l}\text { Patient } \\
4\end{array}$ & $\begin{array}{l}\text { Behcet } \\
\text { dis. }\end{array}$ & Vasculitis & $20 / 125$ & $20 / 100$ & $2+$ & \pm \\
\hline $\begin{array}{l}\text { Patient } \\
5\end{array}$ & $\begin{array}{l}\text { Behcet } \\
\text { dis. }\end{array}$ & Vasculitis & $20 / 200$ & $20 / 100$ & $2+$ & \pm \\
\hline $\begin{array}{l}\text { Patient } \\
6\end{array}$ & Sarcoidosis & Vasculitis & $20 / 40$ & $20 / 28$ & $2+$ & \pm \\
\hline $\begin{array}{l}\text { Patient } \\
7\end{array}$ & $\begin{array}{l}\text { Multifocal } \\
\text { choroiditis }\end{array}$ & Chorioretinitis & $\mathrm{CF}$ & CF & $1+$ & $1+$ \\
\hline
\end{tabular}

Conclusion In this preliminary open trial, infliximab treatment appears to be a useful option in the short term for the management of refractory PU patients with retinal vasculitis.

\section{THU0236 UNDIFFERENTIATED CONNECTIVE TISSUE DISEASE: OUTCOME OF 40 PATIENTS}

M Romero, MA Aguirre, A Cisnal, P Font, MJ Cuadrado, FG Martinez, J Gonzalez, A Escudero, V Perez, C Castro, MC Muñoz-Villanueva, E Collantes. Rheumatology Service, Hospital Universitario Reina Sofia, Cordoba, Spain

10.1136/annrheumdis-2001.768

Background There are a substantial number of patients with symptoms strongly suggestive of a connective tissue disease (CTD) that does not adequately fulfil enough classification criteria to be labelled as such. The outcome of these patients is difficult to predict. They are classified as undifferentiated connective tissue disease (UCTD).

Objectives To prospectively analyse the outcome of a cohort of patients with UCTD. 
Methods Patients with 2 clinical criteria plus 1 serological criteria or 2 serological plus 1 clinical criteria for the classification of any CTD were included. A protocol including clinical and serological parameters was completed at entry in the study and, thereafter, annually. The end point of the study was for the patient to have met enough classification criteria to be labelled as a defined CTD.

Results Forty patients with UCTD (37 women and 3 men, mean age $43 \pm 15$ years and mean follow-up $3.43 \pm 2.5$ years) were included. During the follow-up, 13 patients fulfilled criteria for a defined CTD (32.5\%): 6 fulfilled criteria for rheumatoid arthritis, 4 for systemic lupus erythematosus, 2 for systemic sclerosis and 1 for Sjogren`s syndrome. Sixteen patients still remained unclassified (40\%) and 11 patients $(27.5 \%)$ were completely asymptomatic. There was no association between clinical or serological parameters and outcome.

Conclusion After a mean follow-up of 3.5 years, one third of the UCTD patients evolved into a defined CTD. We found no clinical or serological factors to predict outcome.

\section{THU0237 ENBREL ${ }^{\circledR}$ (ETANERCEPT) IN PATIENTS WITH PSORIATIC ARTHRITIS AND PSORIASIS}

'PJ Mease, 'BS Goffe, ${ }^{1} \mathrm{~J}$ Metz, ${ }^{1} \mathrm{~A}$ VanderStoep, ${ }^{2} \mathrm{DJ}$ Burge. ${ }^{1}$ Clinical Rheumatology, Minor and James Medical; ${ }^{2}$ Clinical Rheumatology, Immunex, Seattle, WA, USA

\subsection{6/annrheumdis-2001.769}

Background Results have been previously presented from a 12week, double-blind placebo-controlled study of 60 patients with psoriatic arthritis (PsA) and psoriasis. ${ }^{1}$ ENBREL was well tolerated and provided clinically significant benefit to patients with PsA and psoriasis. All patients could receive open-label ENBREL in a 24-week extension study.

Objectives Observe the safety and clinical benefit of ENBREL in a longer-term open-label study.

Methods In the extension study, as in the blinded study, we evaluated improvements in patients with PsA according to PsA response criteria (PsARC) and ACR criteria. Patients with psoriasis were evaluated using the Psoriasis Area and Severity Index (PASI).

Results Fifty-eight patients from the 12-week study received open-label ENBREL in the 24-week extension study and were evaluated according to PsARC and ACR criteria. Thirty-seven patients with psoriasis were evaluated using the PASI. The original ENBREL patients sustained their improvement in both PsA and psoriasis in the extension study. The original placebo patients demonstrated similar improvements once they began receiving ENBREL. At 36 weeks of therapy, $81 \%$ of all patients achieved the PsARC, 74\% achieved the ACR 20, and 55\% achieved the ACR 50. The patients with psoriasis $(n=37)$ achieved median improvements of $62 \%$ in the PASI and $50 \%$ in the target lesion response. Of the 28 patients who were taking concomitant methotrexate (MTX) at baseline, 43\% (12/28) have decreased their MTX dose and 25\% (7/28) patients have discontinued MTX. Similarly, of 18 patients on corticosteroids at baseline, 67\% (12/18) have decreased their steroid dose and 44\% (8/ 18) have discontinued steroids. At 36 weeks, $28 \%$ of patients had zero tender joints, $41 \%$ had zero swollen joints, and $40 \%$ had a disability score of zero. ENBREL continued to be well tolerated, with no serious adverse events or infections and no increases in adverse events with extended exposure.
Conclusion ENBREL continues to be safe and effective in reducing the clinical signs and symptoms of PsA and psoriasis for up to 36 weeks.

\section{REFERENCE}

1 Mease PJ, Goffe BS, Metz J, et al. Etanercept in the treatment of psoriatic arthritis and psoriasis: a randomized trial. Lancet 2000;356:385-90

\section{THU0238 ACTIVATED INF-?? AND IL-18 IN ADULT ONSET STILL'S DISEASE}

YB Park, SH Lee, SK Lee. Internal Medicine, Yonsei University College of Medicine, Seoul, Korea

10.1136/annrheumdis-2001.770

Background Adult onset Still's disease (AOSD) is a systemic inflammatory disease in adults. The clinical and laboratory findings of AOSD are well known, however, the cause and pathophysiology of AOSD are scarcely understood. One characteristic finding of AOSD is a reticuloendothelial system activation, which is showed up as lymphadenopathy, hepatosplenomegaly, elevated serum ferritin levels, and combined hemophagocytic syndrome in severe cases.

Objectives To figure out the cytokine network in AOSD, we measured the levels of serum cytokines related to macrophages which is major cell in reticuloendothelial system.

Methods The subjects of the present study were 19 patients diagnosed with AOSD according to Yamaguchi criteria from 1998.6 to 2000.3. Sixty-three serial blood samples were obtained from these nineteen AOSD patients (male:5, female:14) and also blood samples were obtained from age- and sexmatched 16 healthy adults as controls. Serum levels of tumour necrosis factor- $\alpha($ TNF- $\alpha$ ), interleukin- $1 b$ (IL-1b), interferon- $\gamma$ (INF- $\gamma$ ), interleukin-12 (IL-12), interleukin-12 p40 (IL-12 p40), interleukin-15(IL-15), and interleukin-18(IL-18) were measured by the ELISA method. Serum ferritin and C-reactive protein levels were measured by nephelometry. Regression analysis (mixed effect model) was used to correct the effect of serial samples in each individual.

Results Mean age of AOSD patients was 35.53/411.3 years. Nine patients had serious clinical courses which demanded more than once steroid pulse therapy and/or cyclophosphamide therapy. Four cases had died despite having received intensive care (3: disseminated intravascular coagulation (DIC) and shock, 1: heart failure), and hemophagocytic syndrome was confirmed by bone marrow biopsy in one pancytopenic patient. Serum levels of IL$1 b$, IL-12 p40, IL-15, IL-18, TNF- $\alpha$, and INF- $\gamma$ were significantly higher in AOSD patients. INF- $\gamma$ levels well correlated with serum ferritin levels that reflect the disease activity of AOSD. The cytokines that correlated with INF- $\gamma$ were IL-18 and TNF- $\alpha$, not IL-12 or IL-15. IL-18 levels well correlated with INF- $\gamma$, but it did not correlate with TNF- $\alpha$ and ferritin levels. Conclusion Macrophage related cytokines were activated in AOSD patients. INF- $\gamma$ levels correlated with serum ferritin levels, and the activation pathway of INF- $\gamma$ in AOSD was thought to be through IL-18, not IL-12 or IL-15. 